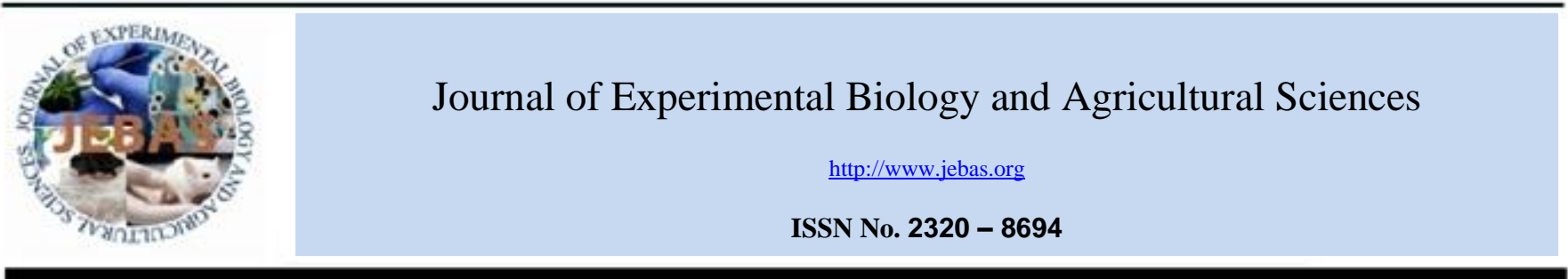

\title{
PHYSICOCHEMICAL CHARACTERISTICS AND MELISSOPALYNOLOGICAL ANALYSIS OF COMMERCIAL BUCKWHEAT HONEYS FROM POLAND
}

\author{
Maciej S. Bryśr ${ }^{1,2}$, Magdalena Kunat ${ }^{1}$, Ernest Stawiarz ${ }^{3}$, Aneta A. Ptaszyńska ${ }^{1 *}$ \\ ${ }^{1}$ Department of Immunobiology, Institute of Biological Sciences, Faculty of Biology and Biotechnology, Maria Curie-Skłodowska University, Akademicka 19 Str., $20-033$ \\ Lublin \\ ${ }^{2}$ The National Institute of Horticultural Research, Division of Apiculture, Kazimierska 2A Str., 24-100 Puławy, Poland \\ ${ }^{3}$ Department of Botany and Plant Physiology, Institute of Plant Biology, Faculty of Environmental Biology, University of Life Sciences in Lublin, Akademicka 15 Str., \\ 20-950 Lublin
}

Received - January 18, 2021; Revision - March 16, 2021; Accepted - April 08, 2021

Available Online - April 25, 2021

DOI: http://dx.doi.org/10.18006/2021.9(2).200.205

\section{KEYWORDS \\ Buckwheat honeys \\ Honeys type \\ Fagopyrym \\ Commercial honey}

\begin{abstract}
Buckwheat honey is widely consumed by consumers due to its numerous health-promoting properties. Characteristically it is dark, tea-like in colour, sharp, tickly, and sweet in flavour, and has smelled of buckwheat flowers. In the current study, various commercial honey samples were examined to test the quality of buckwheat honey samples available in the market. The research materials were comprised of 15 samples of honeys from 4 voivodships, among these, 5 samples were collected from the Świętokrzyskie Voivodship, 4 from the Lesser Poland Voivodeship, 4 from the Lubelskie Voivodship, and reset 2 samples from the Podkarpackie Voivodship. Melissopalynological analyses of investigated honeys' samples revealed that all samples had at least $45 \%$ of Fagopyrym pollen content, which means that researched honeys complied with the standards of the International Commission for Bee Botany (ICBB) for buckwheat honey. Honeys' samples had an average water content of $15.3 \%(\sigma=1.24)$, and electrical conductivity at $0.37 \mathrm{mS}^{*} \mathrm{~cm}^{-1}$. Therefore, all beekeepers correctly marked their honey type as buckwheat honey simply using the organoleptic properties of their honeys and observing their bees collecting pollen and honeydew.
\end{abstract}

* Corresponding author

E-mail: aneta.ptaszynska@poczta.umcs.lublin.pl (Aneta A. Ptaszyńska)

Peer review under responsibility of Journal of Experimental Biology and Agricultural Sciences.

Production and Hosting by Horizon Publisher India [HPI] (http://www.horizonpublisherindia.in/).

All rights reserved.
All the articles published by Journal of Experimental Biology and Agricultural Sciences are licensed under a Creative Commons Attribution-NonCommercial 4.0 International License Based on a work at www.jebas.org.

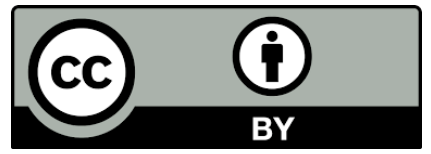




\section{Introduction}

Buckwheat (Fagopyrum esculentum Moench) is one of the most useful plants both for honeybees and other pollinators. This taxon provides insects with large amounts of nectar and pollen throughout the summer and its honey yield ranges from 40 to 494 kilograms from one hectare (Pasini et al., 2013). Buckwheat honeys are some of the most popular types of honey in Eastern Europe, including Poland. Nonetheless, they are also produced in Canada, California, and China (Dalby, 2000; Persano et al., 2004; Pasini et al., 2013).

All varieties of buckwheat honey are specific in their organoleptic characteristics. This honey is dark, tea-like in colour, and turns brown after it has crystallized. Its flavour is sweet, sharp, and tickly. The fragrance is similar to that of buckwheat flowers (Salonen, 2011; Panseri et al., 2013). Fagopyrym pollen is frequently found in multiflorous honeys (Pasini et al., 2013). The most common constituents in buckwheat honeys are aldehydes like 3-methylbutanal, 2-methylbutanal and the short-chain carboxylic acid isovaleric acid (3-methylbutyric acid), which may be used as markers for this type of honey (Machado et al., 2020). Buckwheat honeys are very salubrious, and nutrient-rich source for a wealth of health benefits, such as anti-inflammatory and antibacterial properties, natural antioxidants properties, high contents of sugars, proteins, and total phenols, boost in heart health, prevention of certain cancers, and stronger immune system (Schramm et al., 2003; Brudziński et al, 2012; Panseri et al., 2013; Deng et al., 2018). Furthermore, buckwheat honeys exhibit high antibacterial activity against Staphylococcus aureus and Pseudomonas aeruginosa (Deng et al., 2018).

Real buckwheat honey has many valuable health properties; therefore this research aimed to check whether the commercial honeys available on the market were well assigned as buckwheat honeys.

\section{Materials and Methods}

The research on honey types was carried out under the laboratory of the Immunobiology, Departments of the Maria CurieSkłodowska University. The study material was collected from commercial apiaries situated in south-eastern Poland. In total, 15 samples were collected from 4 voivodships, including 5 samples from the Świętokrzyskie Voivodship, 4 samples from the Lesser Poland Voivodship, 4 samples from the Lubelskie Voivodship, and 2 samples from the Podkarpackie Voivodship. All samples were collected in 2017.

Water content in the samples was estimated using the PAL-22S refractometer (Tahoun \& Shehata 2015). A small amount of liquid honey was placed on the refractometer's prism and the percentage content of water was read in turn. The result was expressed in the arithmetic mean from three readings.

The electrical conductivity was measured in the honey solution at the temperature of $20^{\circ} \mathrm{C}$ using the TDS/EC conductometer. For this, $\mathrm{M}=(5 \mathrm{~g} * 100 \%) / \mathrm{MS}$ formula was used, where $\mathrm{M}$ was the necessary weight $(\mathrm{g}), \mathrm{MS}$ is the dry mass content, which equaled $100 \%$ of dry mass (\%) (Živkov et al. 2018). The arithmetic mean from three consecutive readings was used to obtain the final result.

Pollen analysis was performed under the guidelines of the International Commission for Bee Botany (ICBB) (Louveaux et al., 1970). $10 \mathrm{~g}$ of honey was scooped from every honey sample and $20 \mathrm{ml}$ of distilled water was added in and mix well to dissolve it completely. The resulting suspension was centrifuged twice in the 5804R centrifuge for 10 minutes at 3,000 revolutions per minute. The sediment was suspended in $2 \mathrm{ml}$ of liquid which was left above the sediment with pollen grains. An automatic pipette was used to place $50 \mu 1$ of properly mixed suspension onto slide glasses. The examination under the Olympus CX21 light microscope was carried out at the magnification that was most suitable for identifying the various elements in the sediment $(400$ to $1000 \mathrm{x}$ ). The microscopy analysis was administered using the 600-time engagement. At least 300 grains of pollen grains from nectar-yielding pollen plants were counted. The main types and densities of pollen grains and the relative frequencies of each pollen type were determined according to Panseri et al. (2013). The sum of pollen grains from nectar-yielding pollen was adopted as $100 \%$, and subsequently, the percentage share of each taxon was calculated. On the behalf of observations, four share groups were used and these are predominant pollen types with at least $45 \%$ share in the sample (D); secondary pollen types with the share ranging from 16 to $45 \%$ in the sample (S); important minor pollen types with the share ranging from 3 to $16 \%$ (I); and minor pollen types with the share in the sample not exceeding $3 \%(\mathrm{R})$. The share of the Fagopyrum pollen needed to amount to at least $45 \%$ for the honey to be classified as buckwheat honey.

\subsection{Statistical Analysis}

The data were analyzed using statistical methods and software Statistica (version 12.0, StatSoft Inc., USA) at the significance level of $\alpha=0.05$. The comparisons of quantitative variables in two groups were conducted with either the Student t-test (in the case of normal distribution in both groups) or with Man-Whitney test (otherwise).

\section{Results and Discussion}

Physicochemical characteristics of the buckwheat honey are represented in table 1 , these results revealed that the sample from the Świętokrzyskie Voivodship had the lowest percentage content 
Table 1 Physicochemical characteristics of the examined honeys

\begin{tabular}{|c|c|c|c|c|c|}
\hline & \multirow{2}{*}{ Sample No. } & \multicolumn{3}{|c|}{ Participation in the sample (\%) } & \multirow{2}{*}{$\begin{array}{l}\text { Electrical conductivity } \\
\quad\left(\mathrm{mS} \cdot \mathrm{cm}^{-1}\right)\end{array}$} \\
\hline & & Fagopyrum pollen & water & sugars & \\
\hline \multirow{2}{*}{ Podkarpackie } & 1 & 48.0 & 17.7 & 82.3 & 0.32 \\
\hline & 2 & 46.0 & 19.1 & 80.9 & 0.44 \\
\hline \multirow{4}{*}{ Lesser Poland } & 1 & 68.0 & 16.2 & 83.8 & 0.37 \\
\hline & 2 & 45.0 & 19.0 & 81.0 & 0.35 \\
\hline & 3 & 62.2 & 16.8 & 83.2 & 0.39 \\
\hline & 4 & 45.5 & 18.2 & 81.8 & 0.28 \\
\hline \multirow{5}{*}{ Świętokrzyskie } & 1 & 68.1 & 18.2 & 81.8 & 0.29 \\
\hline & 2 & 49.0 & 17.7 & 82.3 & 0.33 \\
\hline & 3 & 69.0 & 16.8 & 83.2 & 0.38 \\
\hline & 4 & 50.5 & 15.3 & 84.7 & 0.32 \\
\hline & 5 & 46.0 & 15.6 & 84.4 & 0.44 \\
\hline \multirow{4}{*}{ Lubelskie } & 1 & 53.0 & 15.6 & 84.4 & 0.40 \\
\hline & 2 & 60.5 & 18.0 & 82.0 & 0.39 \\
\hline & 3 & 45.0 & 19.0 & 81.0 & 0.43 \\
\hline & 4 & 50.0 & 16.2 & 83.8 & 0.38 \\
\hline
\end{tabular}

A
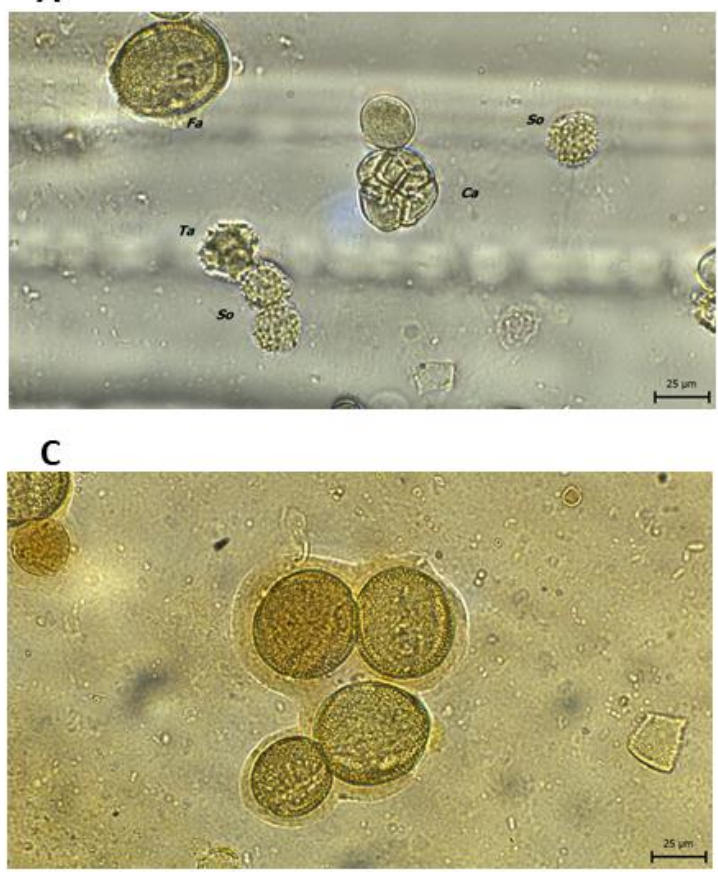

B

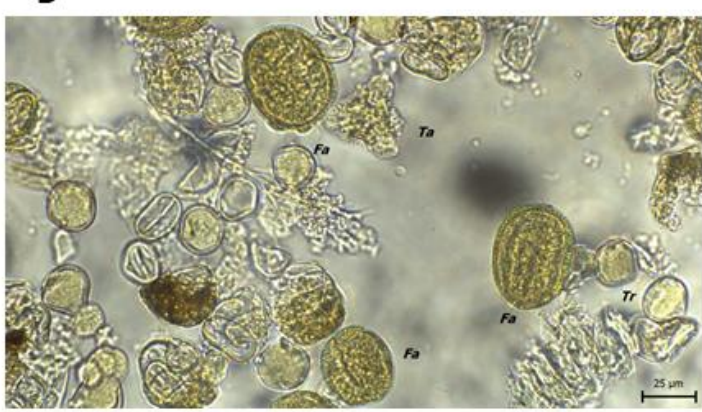

D

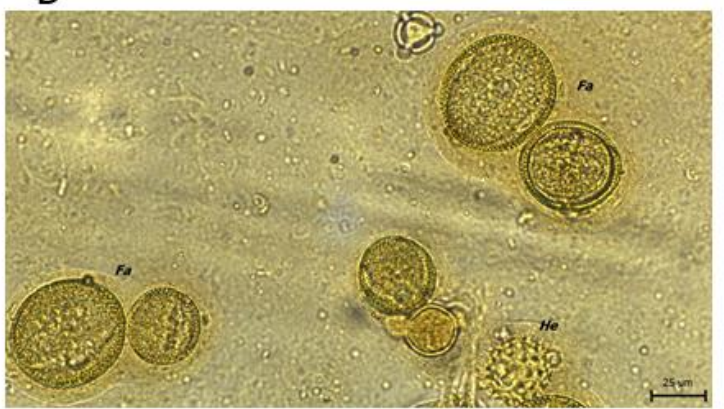

Figure 1 Microscopic images of honey samples with Fagopyrum pollen grains. A. The honey sample from LubelskieVoivodship,

B. The honey sample from Podkarpackie Voivodship, C. The honey sample from Lesser Poland Voivodship, D. The honey sample from Świętokrzyskie Voivodship. Abbreviations: Ca-Calluna, Fa- Fagopyrum, He-Helianthus type, So- Solidago type, TaTaraxacum type, $T r$ - Trifolium repenss 
Table 2 Pollen taxa of nectariferous plants and their contribution in honeys of southeast Poland

\begin{tabular}{|c|c|c|c|c|c|c|c|c|c|c|c|c|c|c|c|c|}
\hline \multirow{3}{*}{\multicolumn{2}{|c|}{ Taxa }} & \multicolumn{15}{|c|}{ Nectariferous plants - voivodship and sample No } \\
\hline & & \multicolumn{2}{|c|}{ Podkarpackie } & \multicolumn{4}{|c|}{ Lesser Poland } & \multicolumn{5}{|c|}{ Świętokrzyskie } & \multicolumn{4}{|c|}{ Lubelskie } \\
\hline & & 1 & 2 & 1 & 2 & 3 & 4 & 1 & 2 & 3 & 4 & 5 & 1 & 2 & 3 & 4 \\
\hline \multicolumn{2}{|l|}{ Fagopyrym } & $\mathrm{D}$ & $\mathrm{D}$ & $\mathrm{D}$ & $\mathrm{D}$ & $\mathrm{D}$ & $\mathrm{D}$ & $\mathrm{D}$ & $\mathrm{D}$ & $\mathrm{D}$ & $\mathrm{D}$ & $\mathrm{D}$ & $\mathrm{D}$ & $\mathrm{D}$ & $\mathrm{D}$ & $\mathrm{D}$ \\
\hline \multicolumn{2}{|l|}{ Phacelia } & & $\mathrm{R}$ & $\mathrm{R}$ & $\mathrm{S}$ & $\mathrm{R}$ & $\mathrm{R}$ & $\mathrm{S}$ & $\mathrm{S}$ & $\mathrm{R}$ & $\mathrm{R}$ & $\mathrm{R}$ & $\mathrm{R}$ & $\mathrm{R}$ & & $\mathrm{R}$ \\
\hline \multicolumn{2}{|l|}{ Solidago type } & $\mathrm{R}$ & $\mathrm{S}$ & $\mathrm{R}$ & $\mathrm{R}$ & $\mathrm{R}$ & $\mathrm{R}$ & $\mathrm{R}$ & $\mathrm{R}$ & & $\mathrm{R}$ & $\mathrm{S}$ & $\mathrm{R}$ & & $\mathrm{S}$ & $\mathrm{S}$ \\
\hline \multicolumn{2}{|l|}{ Salix } & & $\mathrm{R}$ & $\mathrm{R}$ & $\mathrm{R}$ & $\mathrm{R}$ & & $\mathrm{R}$ & $\mathrm{R}$ & $\mathrm{R}$ & $\mathrm{R}$ & $\mathrm{R}$ & $\mathrm{R}$ & & & $\mathrm{R}$ \\
\hline \multicolumn{2}{|l|}{ Trifolium repenss.l. } & & $\mathrm{R}$ & & $\mathrm{R}$ & $\mathrm{R}$ & & $\mathrm{R}$ & $\mathrm{R}$ & $\mathrm{R}$ & $\mathrm{R}$ & $\mathrm{R}$ & $\mathrm{R}$ & & $\mathrm{R}$ & $\mathrm{R}$ \\
\hline \multicolumn{2}{|l|}{ Prunus type } & $\mathrm{R}$ & & $\mathrm{R}$ & $\mathrm{R}$ & & & $\mathrm{R}$ & $\mathrm{R}$ & $\mathrm{R}$ & $\mathrm{R}$ & & $\mathrm{R}$ & $\mathrm{R}$ & $\mathrm{R}$ & \\
\hline \multicolumn{2}{|l|}{ Centaurea cyanus } & & $\mathrm{R}$ & & $\mathrm{R}$ & $\mathrm{R}$ & $\mathrm{R}$ & $\mathrm{R}$ & & & & $\mathrm{R}$ & $\mathrm{R}$ & $\mathrm{R}$ & & $\mathrm{R}$ \\
\hline \multicolumn{2}{|l|}{ Achillea type } & $S$ & $\mathrm{R}$ & & $\mathrm{R}$ & & $\mathrm{R}$ & & & $\mathrm{S}$ & & $\mathrm{R}$ & $\mathrm{R}$ & & $\mathrm{R}$ & \\
\hline \multicolumn{2}{|l|}{ Brassicaceae (other) } & & $\mathrm{R}$ & $\mathrm{S}$ & $\mathrm{R}$ & & & $\mathrm{R}$ & & $\mathrm{R}$ & & $\mathrm{R}$ & $\mathrm{R}$ & $\mathrm{R}$ & & \\
\hline \multicolumn{2}{|l|}{ Helianthus type } & $\mathrm{R}$ & & $\mathrm{R}$ & & $\mathrm{R}$ & & & $\mathrm{R}$ & $\mathrm{R}$ & $\mathrm{R}$ & & $\mathrm{R}$ & $\mathrm{R}$ & & \\
\hline \multicolumn{2}{|l|}{ Taraxacum type } & & $\mathrm{R}$ & $\mathrm{R}$ & $\mathrm{R}$ & $\mathrm{R}$ & & & & $\mathrm{R}$ & & $\mathrm{R}$ & & & $\mathrm{R}$ & $\mathrm{R}$ \\
\hline \multicolumn{2}{|l|}{ Aster type } & & & $\mathrm{R}$ & & & $\mathrm{R}$ & $\mathrm{R}$ & $\mathrm{R}$ & & $\mathrm{R}$ & & I & & & \\
\hline \multicolumn{2}{|l|}{ Tilia } & $\mathrm{R}$ & & & & & $\mathrm{R}$ & $\mathrm{R}$ & & $\mathrm{R}$ & & & $\mathrm{R}$ & & $\mathrm{R}$ & \\
\hline \multicolumn{2}{|l|}{ Trifolium pratensa } & & & & $\mathrm{R}$ & & & $\mathrm{R}$ & & $\mathrm{R}$ & $\mathrm{R}$ & $\mathrm{R}$ & & & & \\
\hline \multicolumn{2}{|l|}{ Rubus type } & $\mathrm{R}$ & & & & & $\mathrm{R}$ & & & $\mathrm{R}$ & & & $\mathrm{R}$ & & & \\
\hline \multicolumn{2}{|l|}{ Brassica napus } & & & & & $\mathrm{R}$ & & & & & & & & & $\mathrm{R}$ & $\mathrm{R}$ \\
\hline \multicolumn{2}{|l|}{ Cirsium type } & & & $\mathrm{R}$ & & & $\mathrm{R}$ & & & $\mathrm{R}$ & & & & & & \\
\hline \multicolumn{2}{|l|}{ Aesculus } & $\mathrm{R}$ & & & & & & & & & & & $\mathrm{R}$ & & & \\
\hline \multicolumn{2}{|l|}{ Anthriscus type } & & & $\mathrm{R}$ & & & & & & & & & $\mathrm{R}$ & & & \\
\hline Calluna & & & & & & $\mathrm{R}$ & & & & & & & $\mathrm{R}$ & & & \\
\hline Impatiens & & & & & $\mathrm{R}$ & & & & & $\mathrm{R}$ & & & & & & \\
\hline Malus type & & & & & & & $\mathrm{R}$ & & & $\mathrm{R}$ & & & & & & \\
\hline Caryophyllaceae & & & & & & & & & & $\mathrm{R}$ & & & & & & \\
\hline Convonvulus arvensis & & & & & & & & & & & $\mathrm{R}$ & & & & & \\
\hline Cucurbita pepo & & & & & & & & & & & & & $\mathrm{R}$ & & & \\
\hline & $\begin{array}{l}\text { Nectariferous } \\
\text { plants }\end{array}$ & 8 & 9 & 11 & 12 & 10 & 10 & 11 & 8 & 16 & 10 & 10 & 17 & 6 & 8 & 8 \\
\hline The number of plant taxa in the sample & $\begin{array}{l}\text { wind-pollinated } \\
\text { plants }\end{array}$ & 2 & 2 & 1 & 1 & 4 & 1 & 3 & 2 & 3 & 4 & 2 & 1 & 3 & 3 & 4 \\
\hline & Total & 10 & 11 & 12 & 13 & 14 & 11 & 14 & 10 & 19 & 14 & 12 & 18 & 9 & 11 & 12 \\
\hline
\end{tabular}

Pollen contribution: D - predominant $>45 \%, \mathrm{~S}$ - secondary $16-45 \%, \mathrm{I}$ - important minor $3-15 \%$, R - minor pollen $<3 \%$

of water (15.3\%), whereas the sample from the Podkarpackie average percentage content of water in all samples was $17.4 \%$. Voivodship had the highest content $\left(19.1 \%\right.$ ) (Table 1). The Proper electrical conductivity ranged from $0.28-0.44 \mathrm{mS}^{*} \mathrm{~cm}^{-1}$, 
and the average for all samples was $0.37 \mathrm{mS}^{*} \mathrm{~cm}^{-1}$ (Table 1). All analyzed physicochemical characteristics were following the regulations for honey (EU Council Directive 2014).

The results of melissopalynological analyses are shown as the percentage of each pollen type in table 2. Pollens were classified as predominant (concentration equal to or upper than 45\%), secondary (concentration between $16 \%$ and $45 \%$ ), important minor (concentration between $3 \%$ and $15 \%$ ), or minor pollen (concentration less than 3\%) (Flores et al. 2015). The share of the Fagopyrum pollen in commercial buckwheat honeys ranged from 45.0 to $69.0 \%$ (Table 2). Further, one sample included 8 to 16 taxa of nectar-yielding plants and 1 to 4 taxa of non-nectar-yielding plants. Pollen grains of the Achillea type, the Solidago type, Brassicaceae (others), and Phacelia had secondary shares in the samples. Important minor was classified as Aster type. Minor pollens were classified to Phacelia, Solidago type, Salix, Trifolium repenss, Prunus type, Centaurea cyanus, Achillea type, Brassicaceae (other), Helianthus type, Taraxacum type, Aster type, Tilia, Trifolium pratensa, Rubus type, Brassica napus, Cirsium type, Aesculus, Anthriscus type, Calluna, Impatiens, Malus type, Caryophyllaceae, Convonvulus arvensis, and Cucurbita pepo (Figure 1).

Melissopalynological analyses confirmed beekeepers' declarations and facilitated qualifying all researched samples as buckwheat honey type complying with the International Commission for Bee Botany (ICBB) (Louveaux et al., 1970). The share of the Fagopyrum pollen in the investigated honeys' samples was very high (predominant pollen types in a sample and ranged from $45.0 \%$ to $69.0 \%)$.

Melissopalynological analyses of buckwheat honeys in Poland was investigated since 1966 when Woźna (1966) described buckwheat honeys traded in Poland. The share of Fagopyrum pollen in the studied samples was decidedly lower than the obtained in the current study and ranged from $4.7 \%$ to $38.2 \%$ (Woźna, 1966). On the other hand, Wróblewska (2002) reported the $45.1 \%$ share of the Fagopyrum pollen in the buckwheat honey from Podlasie. Moreover, this author stressed that Fagopyrym pollen had a secondary share in multiflorous honeys from Podlasie. PuścionJakubik et al. (2020) also studied buckwheat honeys being traded in Poland, and according to their findings, the share of Fagopyrum pollen ranged from $33 \%$ to $77 \%$. Having classified three samples as varieties of buckwheat honeys from Lombardy, Panseri et al. (2013) marked the share of Fagopyrum pollen at $45.5 \%, 46.0 \%$, and $52.0 \%$ respectively.

Further, the results of current study also revealed that buckwheat honeys have characteristically low water content, and it ranges from $15.3 \%$ to $19.1 \%$ (Table 1). Generally, information's regarding the availability of water (moisture) content in honeys are in scanty. Although Majewska et al. (2017) reported $18.6 \%$ to $21 \%$ water content in honeys, this difference might be due to the difference in the sampling procedure or time of sampling. Similarly, Dżugan et al. (2020) also reported $16.2 \%$ to $21.0 \%$ water content in the collected samples. While Nešović et al. (2020) obtained values below $17.1 \%$ for the water content of buckwheat honey samples originated from Serbia and Poland.

Electrical conductivity in buckwheat honeys ranged from 0.28 to $0.44 \mathrm{mS}^{*} \mathrm{~cm}^{-1}$, and the average buckwheat conductivity was at 0.37 $\mathrm{mS}^{*} \mathrm{~cm}^{-1}(\sigma=0.05)$ (Table 1$)$. These results are in agreement with the findings of Nešović et al. (2020), those who reported 0.32 and $0.43 \mathrm{mS} \mathrm{cm}^{-1}$ values in the buckwheat honey samples collected from the Serbian region, while for the Polish honey electrical conductivity was reported $0.21 \mathrm{mS} \mathrm{cm}^{-1}$ and $0.28 \mathrm{mS} \mathrm{cm}^{-1}$ Which was the lower than the current study. The results of Majewska et al. (2017) are in agreement with the findings of the current study, these researchers reported proper electrical conductivity from 0.11 to $0.49 \mathrm{mS}^{*} \mathrm{~cm}^{-1}$.

Some other studies showed that in most of the cases the classification of honeys made by their producers was incorrect and when the research honey samples were analyzed and discussed with consideration of the determined pollen concentrations and conductivity, the real honey type was different than the type notified by the manufacturer (Halagarda et al., 2020). However, the current study suggests that the commercial buckwheat honeys had at least $45 \%$ of Fagopyrym pollen content, in this manner current results complied with the standards of the International Commission for Bee Botany (ICBB) (Louveaux et al., 1970). Buckwheat honey samples had an average water content of $15.3 \%$ $(\sigma=1.24)$, and electrical conductivity at $0.37 \mathrm{mS}^{*} \mathrm{~cm}^{-1}$.

\section{Conclusion}

Melissopalynological analyses confirmed beekeepers' declarations and facilitated qualifying all researched samples as buckwheat honey type complying with the International Commission for Bee Botany (ICBB). All beekeepers correctly marked their honey types simply using organoleptic properties of their honeys and observing their bees collecting pollen and honeydew. Conceivably, beekeepers are becoming more aware of the principles of determining the variety of honey. Apparently, buckwheat honey is honey with very distinctive features that allow for its easy identification even without honey melissopalynological analyses and conductivity.

\section{Acknowledgement}

Publication of the article was financed by the Polish National Agency for Academic Exchange under the Foreign Promotion 
Programme (NAWA), for AAP (bee-research.umcs.pl; Api Lab UMCS PPI/PZA/2019/1/00039).

\section{Conflict of interest}

The authors declare that there is no conflict of interest.

\section{References}

Brudzynski K, Abubaker K, Wang T (2012) Powerful bacterial killing by buckwheat honeys is concentration-dependent, involves complete DNA degradation and requires hydrogen peroxide. Frontiers in Microbiology 3: 242.

Dalby R (2000) Classic American honey plant: buckwheat. American Bee Journal 140: 485-486.

Deng J, Liu R, Lu Q, Hao P, Xu A, Zhang J, Tan J (2018) Biochemical properties, antibacterial and cellular antioxidant activities of buckwheat honey in comparison to manuka honey. Food Chemistry 252:243-249 doi 10.1016/j.foodchem.2018.01.115.

Dżugan M, Grabek-Lejko D, Swacha S, Tomczyk M, Bednarska S, Kapusta I (2020) Physicochemical quality parameters, antibacterial properties and cellular antioxidant activity of Polish buckwheat honey. Food Bioscience 34: 100538. DOI: https://doi.org/10.1016/j.fbio.2020.100538.

EU Council Directive (2014) 2001/110/EC of 20 December 2001 relating to honey. 2002 OJEC. L10, 47-51. Available at https://eur-lex.europa.eu/eli/dir/2001/110/2014-06-23 access on 21st December 2020.

Flores MSR, Escuredo O, Seijo MC (2015) Assessment of physicochemical and antioxidant characteristics of Quercuspyrenaica honeydew honeys. Food Chemistry166: 101-106.

Halagarda M, Groth S, Popek S, Rohn S, Pedan V (2020) Antioxidant Activity and Phenolic Profile of Selected Organic and Conventional Honeys from Poland. Antioxidants (Basel). 9(1): 44. https://doi.org/10.3390/antiox9010044.

Louveaux J, Maurizio A, Vorwohl G (1970) Methods of melissopalynology (republished and updated). Bee World 59: 139-157.

Machado AM, Miguel MG, Vilas-Boas M, Figueiredo AC (2020) Honey Volatiles as a Fingerprint for Botanical Origin-A Review on their Occurrence on Monofloral Honeys. Molecules 25: 374. DOI: https://doi.org/10.3390/molecules25020374.

Majewska E, Drużyńska B, Kowalska J, Wołosiak R, Ciecierska M, Derewiaka D (2017) Zastosowanie metod fizykochemicznych i chemometrycznych do oceny jakości i autentyczności botanicznej miodów gryczanych. Zeszyty Problemowe Postępów Nauk Rolniczych 589: 59-68.

Nešović M, Gašić U, Tosti T, Horvacki N, Šikoparija B, Nedić N, Blagojević S, Ignjatović L, Tešić Ž (2020) Polyphenol profile of buckwheathoney, nectar and pollen. Royal Society Open Science 7: 201576. https://doi.org/10.1098/rsos.201576.

Panseri S, Manzo A, Chiesa LC, Giorgi A (2013) Melissopalynological and Volatile Compounds Analysis of Buckwheat Honey from Different Geographical Origins and Their Role in Botanical Determination. Journal of Chemistry https://doi.org/10.1155/2013/904202.

Pasini F, Gardini S, Marcazzan S, Caboni M (2013) Buckwheat honeys: Screening of composition and properties. Food Chemistry 141: $2802-2811$.

Persano OL, Piana L, Bogdanov S, Bentabol A, Gotsiou P, Kerkvliet J, Martin P, Morlot M, Ortiz-Valbuena A, Ruoff K, Von der Ohe K (2004) Botanical species giving unifloral honey in Europe. Apidologie 35: 82-93.

Puścion-Jakubik A, SochaK, Borawska MH (2020) Comparative study of labelled bee honey from Poland and the result of the melissopalynological analysis, Journal of Apicultural Research 59 (5): 928-938. DOI: 10.1080/00218839.2020.1726035.

Salonen A (2011) Boreal unifrolar honeys: Screening of composition and properties. Publications of the University of Eastern Finland. Dissertations of University of Eastern Finland in Forestry and Natural Sciences, downloaded from http://epublications.uef.fi/pub/urn_isbn_978-952-61-0589-

5/urn_isbn_978-952-61-0589-5.pdf.

Schramm DD, Karim M, Schrader HR, Holt RR, Cardetti M, Keen CL (2003) Honey with High Levels of Antioxidants Can Provide Protection to Healthy Human Subjects. Journal of Agricultural and Food Chemistry 51: 1732-1735. doi: 10.1021/jf025928k.

Tahoun IF, Shehata AB (2016) Preparation of Honey Reference Material for Water Content by Karl Fisher and Refractometric Methods. MAPAN 31: 25-29 doi:10.1007/s12647-015-0156-y.

Woźna J (1966) Obraz pyłkowy i barwa niektórych odmianowych miodów handlowych. Pszczelnicze Zeszyty Naukowe 10: 1-4.

Wróblewska A (2002) Rośliny pożytkowe Podlasia w świetle analizy pyłkowej produktów pszczelich. PracahabilitacyjnaWydawnictwoAkademiiRolniczej w Lublinie.

Živkov BM, Popov N, Vidaković S, LjubojevićPelić D, Pelić M, MihaljevŽeljko, Jakšić S (2018) Electrical conductivity and acidity of honey. Archives of Veterinary Medicine 11: 91-101. 